\title{
Protectionism Actually Hurts U.S. Jobs And Economy: An Investigation Of Proponents And Opponents
}

Ki Hee Kim, (E-mail: kimk@wpunj.edu), William Paterson University C.K. Leung, William Paterson University

\begin{abstract}
Outsourcing is an issue that is generating a lot of debate in the Pacific Northwest, often in response to stories about job cuts and fears that workers will get left out in the cold. However, much of what we read and hear about outsourcing is based on misinformation, no information, or just plain politics. Every major national study confirms that outsourcing creates more jobs than it destroys in the U.S. One of the most persistent complaints against globalization is that it destroys jobs. Many people believe that, the more shoes or cars or steel beams we import to the U.S., the fewer we produce ourselves and the fewer Americans with jobs in those industries. Anxiety about trade and jobs is especially acute about imports from poor countries, where workers typically earn a fraction of the wages earned by American workers. The most ardent proponents of free trade will grant that its benefits are not universally distributed, while it almost always outweighs the costs. Along with the many winners come smaller but still real numbers of losers: people whose jobs are indeed put in jeopardy and even eliminated by competition from imports. For those people, the benefits of lower prices, higher quality, and wider consumer choices can be swamped, at least temporarily, by the trauma of losing their jobs. The purpose of this research is to investigate the advantages and disadvantages of protectionism and its impacts on U.S. jobs and the economy.
\end{abstract}

\section{INTRODUCTION}

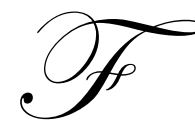

ears about job losses and chronic job shortages are on the loose again. Over the past few years, Millions of U.S. jobs have disappeared, and foreign competition is increasingly taking the blame. Manufacturing jobs are supposedly fleeing to China while service-sector jobs are being "offshore" to India. Job losses are always painful, and recent recession and sluggish recovery have meant real hardship for many Americans. It is important, however, to shun hysteria and demagoguery in assessing what is going on with the labor market and why. The employment picture today is that of a temporary, cyclical shortage of jobs caused by the recent downturn; there is no permanent shortage of good jobs on the horizon. Even in good times, job losses are an inescapable fact of life in a dynamic market economy. Old jobs are constantly being eliminated as new positions are created. Total private-sector jobs increased to 17.8 million between 1993 and 2002. To produce that healthy net increase, a breath-taking total of 327.7 million jobs were added, while 309.9 million jobs were lost. In other words, for every one new net privatesector job created during that period, 18.4 million gross job additions had to offset 17.4 million gross job losses. International trade contributes only modestly to this frenetic job turnover. Between 2000 and 2003, manufacturing employment dropped by nearly 2.8 million, yet imports of manufactured good rose only 0.6 percent. There is no significant difference between jobs lost because of trade and those lost because of technologies or work processes. This paper will examine important issues of protectionism and its positive and negative consequences for both US economy and jobs.

\section{WHAT IS "FAIR TRADE"?}

Let us now turn to some of the leading protectionist arguments. Take, for example, the standard complaint that while the protectionist "welcomes competition," this competition must be "fair." Whenever someone starts talking 
about "fair competition" or indeed, about "fairness" in general, it is time to keep sharp eye on your wallet, for it is about to be picked. For the genuinely "fair" are simply the voluntary terms of exchange, mutually agreed upon by buyer and seller. So what could be "unfair" for an American firm to compete with, say, a Taiwanese firm which needs to pay only one-half the wage rates by imposing an equivalent tariff upon the Taiwanese? But does this mean that consumers can never patronize low-cost firms because it is "unfair" for them to have lower costs than inefficient competitors? What the protectionists don't bother to explain is why U.S. wage rates are so much higher than Taiwan.

\section{TRADITIONAL VS. MODERN PROTECTIONISM}

Protectionism has frequently been associated with mercantilism, the belief that it is beneficial to maintain a positive trade balance, and import substitution. There are two main variants of protectionism, depending on whether the tariff is intended to be collected or not. Most modern views of protectionism call for placing tariffs at such a high level as to compel the consumer to buy the domestic product. In this version of protectionism, no tariff revenue is generated for the government and the consumer is burdened both with high prices on the domestic product and no income or other domestic tax relief. Traditional protectionism sees revenue tariffs as a source of government funding, much like a sales tax that can be used to reduce other domestic forms of taxes. Traditional protectionism remains highly dependent on large amounts of imports. It also requires tariffs to be kept at reasonable rates to ensure maximum government revenue.

\section{FREE TRADE VS. WAGES}

Even though trade does not reduce the total number of jobs in our economy, and it is not the primary source of job dislocation, critics of trade expansion contend that trade is nonetheless driving down wages. Specially, they claim we are trading away good-paying jobs in manufacturing for lower-paying jobs in the service sector. As evidence, they point to widely quoted figures that the average real wage in the U.S. has fallen since 1973, and trade with low-wage countries is primarily blame. The argument that trade liberalization through the GATT/WTO has made Americans poorer contradicts the most obvious facts about the U.S. economy. Americans today are living longer, enjoying better health, and consuming more goods and services per capita than ever before.

\section{COSTS OF PROTECTIONISM}

Classical Liberal philosopher John Stuart Mill astutely observed in the last century that "Trade barriers are chiefly injurious to the countries imposing them." It is true today as it was then, for the following reasons:

- Lost Jobs: Protectionism laws raise taxes (tariffs) on imported goods and/or impose limits (quotas) on the amount of goods governments permit to enter into a country. They are laws that not only restrict the choice of consumer goods, but also contribute greatly both to the cost of goods and to the cost of doing business. Moreover, protectionist laws that reduce consumer spending power actually end up destroying jobs.

- $\quad$ Higher Prices: Japanese consumers pay five times the world price for rice because of import restrictions protecting Japanese farmers.

- $\quad$ Higher Taxes: Protectionist laws not only force you to pay more taxes on imported goods, but also raise your general taxes as well.

- Danger to World Peace: "What generates war is the economic philosophy of nationalism: embargoes, trade and foreign exchange controls, monetary devaluation, etc. The philosophy of protectionism is a philosophy of war."

- $\quad$ For every $\$ 1$ billion, you get 20,000 jobs. That's 3.5 million American workers who would have had good manufacturing jobs if we simply had a trade balance.

- We can glean much from the mistakes of the past. In the 1950s and 1960s, governments of many countries in Africa and Latin America erected walls around themselves in the form of trade barriers. Although the industries grew for a brief period, the lack of competition meant that their industries became lazy and fell behind the rest of the world in both technological improvement and growth.

- $\quad$ Federal Reserve Chairman Alan Greenspan warned Congress on Thursday not to rush to impose punitive tariffs on imports from China, saying they would harm U.S. consumers and protect "few if any American 
jobs." It marked Greenspan's most blunt assessment to date that currency-related legislation that has attracted support from two-thirds of the Senate would harm the U.S. economy by driving up prices for the Chinese products Americans crave.

- The protection of infant industries against imports much too often tends to be indiscriminate and creates strong incentives for the infant producers to remain inefficient and to continue demanding protection which then becomes politically difficult to remove. The result is that the infant does not learn and grows up wearing protectionist diapers into premature senility.

- India managed with its own native entrepreneurs to develop industries such as textiles, shipping and steel under British rule, without protection and even despite British hostility. There are other examples of growth without protection, at least of a sustained variety. Fear, not experience, is at the heart of protectionism here.

- $\quad$ Budget deficit, protectionism loom over global economy. Continued budget deficits in the U.S. and other countries coupled with a reversal of globalization could threaten the global economy, says outgoing Federal Reserve Chairman Greenspan.

- $\quad$ The world enjoyed its greatest economic growth during the relatively free trade period of 1945-1970, a period that also saw no major wars. Yet we again see trade barriers being raised around the world by shortsighted politicians. Will the world again end up in a shooting war as a result of these economically-deranged policies? Can we afford to allow this to happen in the nuclear age? "What generates war is the economic philosophy of nationalism: embargoes, trade and foreign exchange controls, monetary devaluation, etc. The philosophy of protectionism is a philosophy of war.

\section{Protectionism: Who Gains?}

- $\quad$ Those who gain from "protectionist" laws are special-interest groups, such as some big corporations, unions, farmers' groups. All of whom would like to get away with charging higher prices and getting higher wages than they could expect in a free marketplace. These special interests have the money and political clout for influencing politicians to pass laws favorable to them. Politicians in turn play on the fears of uninformed voters to rally support for these laws.

- $\quad$ The total number of jobs in the U.S. is largely determined by fundamental macroeconomics factors such as labor supply growth and monetary policy. Trade with other nations does not reduce the number of jobs, but it does quicken the pace at which production shifts from one sector to another.

- When protectionist policies are enacted, certain domestic industries are protected at the expense of others. So in the end, it comes down to which industries can exert the most influence over domestic politics.

- $\quad$ As for developing countries, many actually bought this argument wholesale a generation ago and only today are recovering from its folly. Countries use their comparative advantages over other countries to create value-that is, if have something you like but I hate, like mustard, and you have something I like but you hate, like a blue cheese dressing and bologna sandwich, then we can trade and, although nothing new has been "created," we are both richer.

- Globalization, the integration of national markets through international trade and investment, offers infinite possibilities, greater freedom and new hope for the world's poor. In fact, studies indicate that developing countries with open economies grew by approximately $5 \%$ a year in the 1970 s and 1980s, while those with closed economies grew less than $1 \%$ annually

- $\quad$ Today, 24 developing countries representing about 3 billion people, including China, India, and Mexico, have adopted policies enabling their citizens to take advantage of globalization. The result are that their economies are catching up with rich ones.

- $\quad$ The greatest environmental disasters in recent years have taken place in Eastern Europe and the former Soviet Union. The horrible air pollution caused by state run industries owe nothing to free trade, but resulted form a system of centralized decision-making that valued resources less wisely than a system of decentralized markets with well-established property rights and prudent government regulation.

- $\quad$ The louder politicians have demanded fair trade and each year protectionists discover new moral pretexts for further restricting how American citizens may spend their paychecks. Fair trade is a moral delusion that could be leading to an economic catastrophe. 
- The "Anti-globalization" movement has inspired students and activities in a manner reminiscent of the civil rights and anti-Vietnam was crusades of the 1960's. Activists significantly disrupted a week-long meeting of the World Trade Organization in Seattle.

- In a state where one in three jobs is supported by international trade and boosts economic growth that creates more new jobs. Because free trade lowers costs for consumers and businesses, raises productivity, increase business investment in new products and industries.

- Helping with retraining and employment assistance for those who do lose their jobs so that they can move on to the higher-skilled, higher-paying jobs of the 21 st century rather than trying to hold on the lower-skilled, low-paying jobs of the past.

- Is this "flood" of Japanese products really a menace, to be combated by the U.S. government? Or is the new Japan a godsend to American consumers? Take, for example, the alleged Japanese menace. All trade is mutually beneficial to both parties-in this case (TV sets, autos, microchips, etc.,) Japanese producers and American consumers.

- $\quad$ Another protectionist fallacy held that the government should provide a temporary protective tariff to aid, or to bring into being, an "infant industry." Then when the industry was well-established, the government should and would remove the tariff and toss the now "mature" industry into competitive swim. The theory is fallacious, and the policy has approved disastrous in practice.

- $\quad$ Protectionism would not solve the U.S. economy's employment, although it would succeed in providing massive subsidies to well-organized interest groups.

- $\quad$ There is a danger that the anti-globalization lobbies are teaching a whole new generation the wrong lessons. Regrettably, even some of the most laudable campaigns against poverty in the developing world fail to understand the vital thread that links open markets, free trade, property rights, and the rule of law, economic development and social progress.

\section{Protectionism has unforeseen consequences:}

- Although the industries in Africa and Latin America "protected" countries grew for a brief period, the lack of competition meant that their industries became lazy and fell behind the rest of the world in both technological improvement and growth.

- Protectionism in the world's largest economy could also unsettle global financial markets while doing little to protect jobs in this country.

- $\quad$ The protection of infant industries against imports much too often tends to be indiscriminate and creates strong incentives for the infant producers to remain inefficient and to continue demanding protection which then becomes politically difficult to remove

- $\quad$ Disoriented by the quickened pace of today's competition, some in our society are looking back with nostalgia to the seemingly more tranquil years of the early post-World War II period. Were we to yield to such selective nostalgia and shut out a large part-or all-of imports of manufactured goods and produce them ourselves our overall standards of living would fall.

- $\quad$ Continued budget deficits in the U.S. and other countries coupled with a reversal of globalization could threaten the global economy, says outgoing Federal Reserve Chairman Alan Greenspan.

- $\quad$ For poor countries careful and temporary protectionism can help nurture industries.

- $\quad$ Some aspects of how protectionism can e used by rich countries include:

- Intervention things like tech. transfer, or distorting market functions.

○ Providing vast subsidies to local industries.

$\circ \quad$ One-side trade agreement.

- Even military expeditions to open and expand resource access.

$\circ \quad$ Rich countries practicing protectionism at home when it suits. 


\section{CONCLUSION}

Silence gives consent, and there should be no consent to the current waves of restrictive trade or capital control legislation being passed. A century and a half ago French economist and statesman Frederic Bastiat presented the practical case for free trade: "It is always beneficial," he said, "for a nation to specialize in what it can produce best and then trade with others to acquire goods at costs lower than it would take to produce them at home." In the $20^{\text {th }}$ century, journalist Frand Chodorov make a similar observation: "Society thrives on trade simply because trade makes specialization possible, and specialization increase output, and increased output reduces the cost in toil for the satisfactions men live by. That being so the market place is a most humane institution." No matter how much debates on protectionism, there will be no mutually agreeable solutions between trading partners and trade will go on.

Table 1: U.S. INTERNATIONAL TRADE IN GOODS AND SERVICES BALANCE OF PAYMENTS (BOP) BASIS, 1960-2004 (Billions of Dollars)

\begin{tabular}{|c|c|c|c|c|c|c|c|c|c|}
\hline & \multicolumn{3}{|c|}{ Exports } & \multicolumn{3}{c|}{ Imports } & \multicolumn{3}{c|}{ Trade Balance } \\
\hline & Total & Goods & Services & Total & Goods & Services & Total & Goods & Services \\
\hline 1960 & 25.9 & 19.7 & 6.3 & 22.4 & 14.8 & 7.7 & 3.5 & 4.9 & -1.4 \\
\hline 1965 & 35.3 & 26.5 & 8.8 & 30.6 & 21.5 & 9.1 & 4.7 & 5.0 & -.3 \\
\hline 1970 & 56.6 & 42.5 & 14.2 & 54.4 & 39.9 & 14.5 & 2.3 & 2.6 & -.3 \\
\hline 1975 & 132.6 & 107.1 & 25.5 & 120.2 & 98.2 & 22.0 & 12.4 & 8.9 & 3.5 \\
\hline 1980 & 271.8 & 224.3 & 47.6 & 291.2 & 249.8 & 41.5 & -19.4 & -25.5 & 6.1 \\
\hline 1985 & 288.8 & 215.9 & 72.9 & 410.9 & 338.1 & 72.8 & -122.1 & -122.2 & .1 \\
\hline 1990 & 537.2 & 389.3 & 147.9 & 618.4 & 498.3 & 120.0 & -81.1 & -109.0 & 27.9 \\
\hline 1995 & 793.7 & 575.2 & 218.5 & 888.8 & 749.4 & 139.4 & -95.1 & -174.2 & 79.1 \\
\hline 2000 & $1,070.1$ & 772.0 & 298.1 & $1,445.4$ & $1,224.4$ & 221.0 & -375.4 & -452.4 & 77.0 \\
\hline 2004 & $1,146.1$ & 807.6 & 338.6 & $1,763.9$ & $1,473.8$ & 290.1 & -617.7 & -666.2 & 48.5 \\
\hline
\end{tabular}

NOTE: 1. Compiled from official statistics of the U.S. Department of Commerce, Bureau of Economic Analysis. Data reflect revisions through 2/10/2005 in FT-900 (Exhibit 1).

2. Balance of Payments (BOP) basis for goods reflects adjustments for timing, coverage, and valuation to the data compiled by the Census Bureau. The major adjustments concern: military trade of U.S. defense agencies, additional non-monetary gold transactions and inland freight in Canada and Mexico.

3. Goods valuation are F.a.s. for exports and Customs value for imports.

Table 2: GDP \& U.S. INTERNATIONAL TRADE IN GOODS AND SERVICES, 1976-2004 NATIONAL INCOME AND PRODUCT ACCOUNTS BASIS (Billions) NOMINAL Current Dollars

\begin{tabular}{|c|c|c|c|c|c|c|c|c|}
\hline Year & GDP & Net Exports & $\begin{array}{c}\text { Exports } \\
\text { Total }\end{array}$ & $\begin{array}{c}\text { Exports } \\
\text { Goods }\end{array}$ & $\begin{array}{c}\text { Exports } \\
\text { Services }\end{array}$ & $\begin{array}{c}\text { Imports } \\
\text { Total }\end{array}$ & $\begin{array}{c}\text { Imports } \\
\text { Goods }\end{array}$ & $\begin{array}{c}\text { Imports } \\
\text { Services }\end{array}$ \\
\hline 1976 & $1,825.3$ & -1.6 & 149.5 & 117.8 & 31.7 & 151.1 & 124.6 & 26.5 \\
\hline 1980 & $2,789.5$ & -13.0 & 280.8 & 225.8 & 55.0 & 293.8 & 248.6 & 45.3 \\
\hline 1985 & $4,220.3$ & -115.2 & 302.0 & 222.2 & 79.8 & 417.2 & 343.3 & 73.9 \\
\hline 1990 & $5,803.1$ & -77.9 & 552.4 & 396.6 & 155.7 & 630.3 & 508.1 & 122.3 \\
\hline 1995 & $7,397.7$ & -91.4 & 812.2 & 583.3 & 228.9 & 903.6 & 757.4 & 146.1 \\
\hline 2000 & $9,817.0$ & -379.5 & $1,096.3$ & 784.3 & 311.9 & $1,475.8$ & $1,243.5$ & 232.3 \\
\hline 2004 & $11,735.0$ & -606.2 & $1,175.5$ & 820.3 & 355.1 & $1,781.6$ & $1,490.8$ & 290.8 \\
\hline
\end{tabular}




\section{REFERENCES}

1. Gordon Brown: Globalization is a Race to the Top, September 8, 2005.

2. David Cameron: Anti-Globalization Lobbies are Teaching Wrong Lessons, November 8, 2005.

3. Franklin Cudjoe, Director of Imani, A Think-Tank in Accra, August 11, 2005.

4. Daniel W. Drezner, The Outsourcing Bogeyman, May/June 2004.

5. $\quad$ Brink Lindsey, Job Loses and Trade: A Reality Check, March 17, 2004.

6. Murray N. Rothbard, Protectionism and the Destruction of Prosperity, 1986.

7. George F. Russell Jr., Protectionism's the Wrong Response to Outsourcing, April 2, 2005.

8. Vincent H. Miller, The Lure of Protectionism: http://www.isil.org/resources/lit/free-trade-protectionism.html.

9. Vincent H. Miller \& James R. Elwood, Free Trade Protectionism. http://www.freetrade.org/pubs/nas/tna-002 $\underline{\text { html. }}$

10. $\quad$ Alex Singleton, Protectionism Won't Save Countries from Poverty, August 11, 2005.

11. Alex Singleton, Greenspan Speaks Out Against Anti-Chinese Protection, June 24, 2005.

12. Penny Hawthorne, Protecting Infant Industries Doesn't Work, June 20, 2005.

13. CalTrade Report-Budget Deficits, Protectionism Loom Over Global Economy, December 12, 2005.

14. Stephen Spuriell, Protectionism: Tariffs, Subsides, and Trade Policy.

15. John Manzella, Globalization's Effects.

16. Douglas Irwin, The Free Trade Case: Opened vs. Closed Societies.

17. World Connected-Globalization, Free Trade, Foreign Aid: A Primer.

18. Protectionism-Wikipedia, the free encyclopedia-http://en.wikipedia.org./wiki/protectionism.

19. Alan Greenspan, Capitalism, Protectionism, and Globalization, January 5, 2004.

20. Greenspan, Budget Deficits, Protectionism Loom Over Global Economy, December 8, 2005.

21. Anup Shah, Free Trade and Globalization: Deregulation or Protectionism?, August 4, 2005.

22. World Connected-Globalization, Free Trade, Foreign Aid: A Primer.

23. World Connected-Trade and U.S. Jobs-http//www.aworldconnnected.org/article.php/561/html. 